Egyptian Journal of Aquatic Biology \& Fisheries

Zoology Department, Faculty of Science,

Ain Shams University, Cairo, Egypt.

ISSN $1110-6131$

Vol.25 (5): 645 - 660 (2021)

www.ejabf.journals.ekb.eg

\title{
Effects of different dietary protein and lipids levels on growth performance and digestive enzymes of the rabbitfish (Siganus rivulatus), reared in well water
}

\author{
Mohamed El-Sayed Salem ${ }^{1}$, Heba M. Abdel-Ghany ${ }^{1}$, Ahmed E. Sallam ${ }^{1}$, \\ Mohamed M. M. El-feky ${ }^{2}$ \\ ${ }^{1}$ Aquaculture Division, National Institute of Oceanography and Fisheries, Alexandria, Egypt \\ ${ }^{2}$ Aquatic Resources, Natural Recources studies and Research Department, College of high Asian \\ Studies, Zagazig University, Zagazig, Egypt \\ * Corresponding Author: salem_200080@yahoo.com
}

\begin{tabular}{|c|c|}
\hline ARTICLE INFO & ABSTRACT \\
\hline Article History: & A trial has been evaluated the effects of different levels of dietary protein \\
\hline Received: July 10, 2021 & and lipid on the growth performance, feed utilization, and digestive enzymes of \\
\hline Accepted: Sept. 30, 2021 & the rabbitfish (Siganus rivulatus). Four diets were formulated as follows: diet 1 \\
\hline Online: Oct. 30, 2021 & $\begin{array}{l}\text { (P30L6) (protein 30\% and lipid 6\%), diet } 2 \text { (P30L12) (protein 30\% and lipid } \\
12 \% \text { ), diet } 3 \text { (P40L6) (protein 40\% and lipid 6\%) and diet } 4 \text { (P40L12) (protein }\end{array}$ \\
\hline & $40 \%$ and lipid $12 \%$ ). Diets were fed to the Rabbitfish (S. rivulatus) juveniles \\
\hline Keywords: & $(0.32 \pm 0.16 \mathrm{~g} / \mathrm{fish})$ for 56 days. Fish fed on P40L12 and P40L6 diets showed \\
\hline Rabbitfish; & the best growth, followed by P30L6 and P30L12. Better feed utilization was \\
\hline Siganus rivulatus; & obtained in fish-fed diets with $40 \%$ protein compared to $30 \%$ protein \\
\hline Growth; & regardless of the dietary lipid levels. The highest value of protease has been \\
\hline Digestive enzymes; & recorded in P40 fish groups with both lipid levels followed by P30L12. Fish \\
\hline Lipid; & groups of P30L6, P30L12, P40L6 to P40L12, respectively, showed an increase \\
\hline Protein. & $\begin{array}{l}\text { in lipase upward. The highest result of amylase was detected in P30L6 } \\
\text { followed by P30L6 and P40L6. The highest value of glutamate dehydrogenase } \\
\text { was given in P30L6 followed by P30L12. Thus, the P40L6 diet is suitable for } \\
\text { the optimal growth performance and digestion functions of the Rabbitfish ( } S \text {. } \\
\text { rivulatus) juveniles. }\end{array}$ \\
\hline
\end{tabular}

\section{INTRODUCTION}

Marbled spinefoot (Siganus rivulatus) belongs to the Family Siganidae, commonly known as rabbitfish (Woodland, 1983). Wild S. rivulatus is a coastal dweller feeding on various macrophytes (Anastasiades, 2011). Rabbitfish has been found as a potential warm water candidate for marine aquaculture production due to its good taste and being omnivore feeding on artificial diets (Lam, 1974; Abou-Daoud et al., 2014). Thus, it can provide a cheap protein source on a large production scale. Until now, the rabbitfish 
aquaculture has not been introduced on a commercial large scale. The main reason for that shortage in mass production of the rabbitfish aquaculture may be attributed to the lack of its nutritional requirements knowledge regarding the growth performance. Therefore, an effective grow-out dietary formulation is highly required to not only support the optimal growth, but also to promote the disease resistance in juvenile fish.

From a nutritional perspective, dietary protein is the most important macronutrient in formulated diets affecting growth, health, reproduction, and physiological performance of farmed fish as well as the production costs (Kaushik \& Seiliez, 2010 and Lovell, 1998). In turn, dietary protein requirements are affected by different factors such as species, fish size, age, water temperature, rearing environment and protein quality, as well as genetic characters and feeding regime of fish (Halver \& Hardy, 2002). In specific, the optimal protein level in fish diets is also affected by other dietary factors such as the digestibility efficiency of the protein, its amino acid composition, and the amount of nonprotein energy sources (Halver \& Hardy 2002).

In parallel, dietary lipid is a main source of energy and essential fatty acids that cannot be de novo synthesized by fish (López et al., 2009). Lipids are the main source of metabolic energy for growth from an egg to the adulthood (Mohanta et al., 2008). Fish, as all animals, have specific energy requirements. If the diet does not contain enough nonprotein energy sources, then fish will use the protein for energy to satisfy its maintenance at the expense of its growth (NRC, 1993). In similar, excess dietary protein will be used for energy and not for the production of new tissues resulting in growth retardation and an increase in ammonia excretion (Mohanta et al., 2008). Moreover, use of protein as a source of energy leads to an increase in the production cost (Lee et al., 2002). Thus, a sufficient dietary lipid level was found to improve the feed utilization and growth rate by sparing the protein (Watanabe, 1982; Beamish \& Medland, 1986 and Hardy, 1999). In other words, adequate levels of dietary lipid can minimize the protein utilization. However, exceeding the optimal level of energy can lead to fat deposition, reduced feed consumption and decreased growth performance in fish (Martino et al., 2002; Lin \& Shiau, 2003 and Chaitanawisuti et al., 2011). Thus, a protein-to-energy balance in the feed is essential.

Many studies have focused on the importance of determining the optimal ratio of dietary protein to lipid for fishes, such as juvenile Asian seabass, Lates calcarifer (Catacutan \& Coloso,1995); the rabbitfish, Sigunus guttatus (Parazo, 1990); the brown trout, Salmo trutta fario (Wang et al., 2018) and the loach, Misgurnus anguillicaudatus (Yan et al., 2017). In particular, two previous studies have been carried out to determine the optimum dietary protein ratio for Siganus rivulatus (El-Dakar et al., 2011 and AbouDaoud et al., 2014). They estimated the optimum protein level for the juvenile $S$. rivulatus as $40 \%$. In parallel, only one study (Ghanawi et al., 2011) has addressed the lipid requirement for $S$. rivilatus, which suggested that the dietary lipid requirement for the optimal growth in juvenile marbled spinefoot is $9.8 \%$. Therefore, it is clearly noticeable 
that the optimum protein to lipid ratio rather than the separate protein and lipid levels was not studied yet for the rabbitfish ( $S$. rivulatus).

On the other side, digestion and nutrients absorption are the key processes in the efficient use of diets. Nutrient absorption capacity is highly affected by the diet composition (Buddington et al., 1997). Consequently, the feed utilization efficiency and growth performance will be also affected (García-Meilán et al., 2013). In some species, digestive enzymes such as protease, amylase and lipase increase with any increase in dietary protein, lipids or carbohydrates (Buddington \& Krogdahl, 2004 and GarcíaMeilán et al., 2013). For instance, the nutrient absorption capacity is modified in response to the inclusion of high levels of plant protein sources (Santigosa et al., 2011). Thus, digestive enzymatic activities often reflect the feeding habits of teleosts (German $\boldsymbol{e t}$ al., 2010). However, less is known about how the digestive and absorptive processes interact with the dietary modifications in S. rivulatus. In our knowledge, no studies have been carried out to assess the effect of different protein to lipid ratios on digestive and digestive absorptive processes of the rabbitfish ( $S$. rivulatus).

Accordingly, the purpose of this study was to determine the optimal protein to lipid ratio and its effects on growth performance, feed utilization, digestive enzymes and the body composition of the rabbitfish ( $S$. rivulatus) juveniles.

\section{MATERIALS AND METHODS}

\section{Experimental diets:}

Four semi-purified diets were formulated to contain two crude protein levels, $30 \%$ and 40\%; and each with two crude lipid levels, 6\% and 12\% (Table 1). All dry ingredients were finely ground $(<250 \mu \mathrm{m})$ using a laboratory mill and combined with the other ingredients and micronutrients (vitamins and minerals) prior to mixing. Then, the ingredients were thoroughly mixed together, and then, the lipid was added and thoroughly mixed. The diet mixtures were then extruded into pellets with an appropriate size by a meat grinder (Tornado, MG-2000). All diets were dried in an electric oven at $60^{\circ} \mathrm{C}$ for 24 hours, and then stored in plastic bags at $-20^{\circ} \mathrm{C}$ until use. The fish were fed the diets until apparent satiation 5 times a day.

\section{Experimental fish:}

Rabbitfish (S. rivulatus) juveniles were obtained from the coast of Mediterranean Sea, Alexandria, Egypt. The Rabbitfish juveniles were maintained at the Fish Nutrition Laboratory at the National Institute of Oceanography and Fisheries (NIOF). The experimental system consisted of 12 hapas $(50 \times 50 \times 70 \mathrm{~cm} ; \mathrm{L} \times \mathrm{W} \times \mathrm{H})$. Each three hapas placed in one concrete tank $(5.0 \times 2.0 \times 1.5 \mathrm{~m})$ at least $1 \mathrm{~m}$ apart. Filtered well water (salinity 40\%o) was provided to each tank with a continuous aeration. The water quality parameters were monitored every 2 days throughout the experimental period. 
Water temperature, salinity, dissolved oxygen, ammonia-N, $\mathrm{pH}$ were maintained at $26 \pm$ $2.3^{\circ} \mathrm{C}, 40 \%, 6 \mathrm{mgL}^{-1}, 0.5 \mathrm{mgL}^{-1}$ and 7.8 , respectively. The fish were acclimatized to the hapas for 2 weeks, and they were fed the control diet as an adaptation period prior to the feeding on the experimental diets.

A total of 600 larvae (average weight: $0.32 \pm 0.16 \mathrm{~g} /$ fish) were randomly allocated into 12 hapas at a density of 50 fish per hapa. Each hapa was then randomly assigned to one of three replicates of the four dietary treatments. Faeces were removed after feeding by siphoning. The amount of feed consumed in each treatment was calculated weekly by the difference in the weight of the food containers before and after feeding. The experiment was subjected to natural light conditions.

\section{Productive performance parameters:}

All fish were bulk weighed and measured individually at the beginning, every two weeks, and the end of the experimental period. Survival was measured by the percentage of the final number of fish divided by the initial number of fish. Growth performance and feed utilization were calculated as the following equations:

- Weight gain rate $($ WGR $\%)=\frac{(\text { final weight }- \text { initial weight })}{\text { initial weight }} \times 100$

- Specific growth rate $(\mathrm{SGR})(\% /$ day $)=\frac{\ln (\text { final weight })-\ln (\text { initial weight })}{56 \text { days }} \times 100$

- Daily growth index $($ DGI $)=100 \times \frac{\text { final weight } \frac{1}{3}-\text { initial weight } \frac{1}{3}}{56 \text { days }}$

- Feed efficiency (FE) \% $=100 \times \frac{\text { body weight gain }(\mathrm{g})}{\text { feed intake }(\mathrm{g})}$

- Feed conversion ratio $($ FCR $)=\frac{\text { total dry feed intake }(\mathrm{g})}{\text { total fish weight gain }(\mathrm{g})}$

- Protein efficiency ratio $($ PER $)=\frac{\text { fish weight gain }(\mathrm{g})}{\text { total dry protein intake }(\mathrm{g})}$

- Protein retention $(\mathrm{PR})(\%$ of intake $)=\frac{\text { protein gain }(\mathrm{g} / \mathrm{kg} \text { weight gain })}{\text { protein intake }(\mathrm{g} / \mathrm{kg} \text { weight gain })} \times 100$

\section{Sample collection:}

At the beginning of the trial, 50 fish were randomly collected and frozen at $-20^{\circ} \mathrm{C}$ for further initial whole-body composition analysis. At the end of the feeding trial, the fish were starved for $24 \mathrm{~h}$, and then survival and mass weight per replicate were recorded in all hapas. Twenty fish per hapa were sampled for further analyses. All samples were frozen immediately and stored at $-20{ }^{\circ} \mathrm{C}$ until being analyzed. 
Table (1): Composition and proximate analysis (\%) of the experimental diets fed to $S$. rivulatus

\begin{tabular}{|c|c|c|c|c|}
\hline \multirow{2}{*}{ Feed ingredients (\%) } & \multicolumn{4}{|c|}{ Diets } \\
\hline & P30L6 & P30L12 & P40L6 & P40L12 \\
\hline Fishmeal $^{1}$ & 8.5 & 8.5 & 28.7 & 28.7 \\
\hline Maize gluten $^{2}$ & 9.2 & 9.2 & 11.0 & 11.0 \\
\hline Soybean meal ${ }^{3}$ & 31.5 & 31.5 & 26.7 & 26.7 \\
\hline Wheat meal ${ }^{4}$ & 25.0 & 25.0 & 8.0 & 8.0 \\
\hline Maize starch & 10.0 & 3.6 & 10.0 & 4.0 \\
\hline Ulva sp. powder & 6.0 & 6.0 & 6.0 & 6.0 \\
\hline Brewer's yeast $^{5}$ & 2.0 & 2.0 & 2.0 & 2.0 \\
\hline Sunflower oil & 4.40 & 10.8 & 4.2 & 10.2 \\
\hline Vitamin and Mineral mix ${ }^{6}$ & 1.0 & 1.0 & 1.0 & 1.0 \\
\hline Gelatin as a binder & 1.0 & 1.0 & 1.0 & 1.0 \\
\hline $\mathrm{Ca}\left(\mathrm{H}_{2} \mathrm{PO}_{4}\right)_{2}$ & 0.8 & 0.8 & 0.8 & 0.8 \\
\hline Essential amino acid mixture ${ }^{7}$ & 0.36 & $\begin{array}{l}0 . \\
36\end{array}$ & 0.36 & 0.36 \\
\hline Choline chloride & 0.12 & 0.12 & 0.12 & 0.12 \\
\hline Betaine & 0.1 & 0.1 & 0.1 & 0.1 \\
\hline Vitamin C & 0.02 & 0.02 & 0.02 & 0.02 \\
\hline \multicolumn{5}{|l|}{ Proximate composition $(\%)$} \\
\hline Crude protein & 30.10 & 30.56 & 41.03 & 40.65 \\
\hline Ether extract & 6.34 & 12.48 & 6.84 & 13.04 \\
\hline Protein lipid ratio & 4.75 & 2.45 & 6.00 & 3.12 \\
\hline Ash & 5.23 & 5.08 & 6.73 & 6.67 \\
\hline Moisture & 11.38 & 12.81 & 10.32 & 12.78 \\
\hline Carbohydrate & 58.33 & 51.88 & 45.40 & 39.64 \\
\hline Gross energy $\left(\mathrm{MJ} \mathrm{kg}^{-1}\right)^{8}$ & 19.34 & 20.68 & 19.83 & 21.11 \\
\hline $\mathrm{P} / \mathrm{E}$ ratio $\left(\mathrm{g} \mathrm{MJ}^{-1}\right)^{9}$ & 15.56 & 14.78 & 20.69 & 19.25 \\
\hline
\end{tabular}

${ }^{1}$ Fish meal: crude protein $671.0 \mathrm{~g} \mathrm{~kg}^{-1}$, crude lipid $50.6 \mathrm{~g} \mathrm{~kg}^{-1}$;

${ }^{2}$ corn gluten: crude protein $607.1 \mathrm{~g} \mathrm{~kg}^{-1}$, crude lipid $22.0 \mathrm{~g} \mathrm{~kg}^{-1}$;

${ }^{3}$ soybean meal: crude protein $483.1 \mathrm{~g} \mathrm{~kg}^{-1}$, crude lipid $9.4 \mathrm{~g} \mathrm{~kg}^{-1}$;

${ }^{4}$ wheat meal: crude protein $151.2 \mathrm{~g} \mathrm{~kg}^{-1}$, crude lipid $31.2 \mathrm{~g} \mathrm{~kg}^{-1}$;

${ }^{5}$ Brewer's yeast: crude protein $438.6 \mathrm{~g} \mathrm{~kg}^{-1}$, crude lipid $50.1 \mathrm{~g} \mathrm{~kg}^{-1}$;

${ }^{6}$ Vitamin and Mineral mix : VA, 15000 IU; VC, 1000 mg; VD3, 2500 IU; VK3, 50 mg; VB1, 50 mg; VB2, $20 \mathrm{mg}$; VB6, $30 \mathrm{mg}$; VB12, $0.5 \mathrm{mg}$; VE, $300 \mathrm{mg}$; Niacin, $260 \mathrm{mg}$; Calcium pantothenate, $150 \mathrm{mg}$; Folacin $20 \mathrm{mg}$; Biotin, $2.5 \mathrm{mg}$; Inositol, $100 \mathrm{mg}$. Cu, 8; Zn, 250; Mn, 45; Fe, 100; I, 2.4; Co, 2; Mg, 4;

${ }^{7}$ Contained: L-methonine, 0.1\%; L-lysine, 0.2\%; L-valine, 0.06\%;

${ }^{8}$ Calculated using gross and digestible energy values of $23.01,38.05$ and $17.15 \mathrm{kJg}^{-1} ; 16.84,33.47$ and $10.46 \mathrm{kJg}^{-1}$ for protein, fat and carbohydrate, respectively;

${ }^{9} \mathrm{P} / \mathrm{E}$ : protein/energy $(\mathrm{mg}$ crude protein/kJ gross energy $)=\mathrm{CP} / \mathrm{GE} \times 1,000$.

\section{Biochemical analysis:}

Moisture, ash, crude protein, and lipid contents of all samples were analyzed according to AOAC (2009) methods. Crude protein was determined by the Kjeldahl method using an auto Kjeldahl System (K358/355, BUCHI, Flawil, Switzerland). Crude 
lipid was determined by the ether extraction method using a Soxlet System (VELP Scientific a, SER 248, Italy). Moisture was determined in an oven at $105^{\circ} \mathrm{C}$ for $24 \mathrm{hr}$. Ash was determined using a muffle furnace at $600^{\circ} \mathrm{C}$ for $6 \mathrm{hr}$.

\section{Analysis of the digestive enzymes activities:}

Tissue samples from foregut, midgut and hindgut were homogenized in 4 volumes of ice-cold physiological saline $(0.85 \% \mathrm{w} / \mathrm{v} \mathrm{NaCl})$. Homogenates were centrifuged at $3,500 \mathrm{rpm}$ for $15 \mathrm{~min}$ at $4^{\circ} \mathrm{C}$, and the resulting supernatants were aliquoted and stored at $80{ }^{\circ} \mathrm{C}$ until subsequent analysis. Amylase activity was assayed by SIGMA-ALDRICH kit (Catalog number MAK009). Amylase activity was determined using a coupled enzymatic assay, which resulted in a colorimetric $(405 \mathrm{~nm})$ product, proportional to the amount of the substrate, ethylidenepNP- G7, cleaved by the amylase. One unit was the amount of amylase that cleaved ethylidene-pNP-G7 to generate 1.0 mmole of p-nitrophenol per minute at $25{ }^{\circ} \mathrm{C}$. Glutamate Dehydrogenase (GDH) activity was assayed by SIGMAALDRICH kit (Catalog number MAK099). GDH activity was determined by a coupled enzyme assay in which glutamate was consumed by GDH generating NADH, which reacted with a probe generating a colorimetric $(450 \mathrm{~nm})$ product proportional to the GDH activity. One unit of GDH was the amount of enzyme that generated 1.0 mmole of NADH per minute at $\mathrm{pH} 7.6$ and $37^{\circ} \mathrm{C}$. Lipase activity was assayed by SIGMA-ALDRICH kit (Catalog number MAK046). Lipase activity was determined using a coupled enzyme reaction, which resulted in a colorimetric $(570 \mathrm{~nm})$ product proportional to the enzymatic activity. One unit of lipase is the amount of enzyme that generated $1.0 \mu$ mole of glycerol from triglycerides per minute at $37^{\circ} \mathrm{C}$. Protease was assayed by SIGMA-ALDRICH kit ( Catalog number PF0100). This kit used a modification of the published procedure (Twining, 1984). Protease activity was detected using casein labeled with fluorescein isothiocyanate (FITC) as the substrate. Protease activity resulted in the cleavage of the FITC-labeled casein substrate into smaller fragments, which did not precipitate under acidic conditions. After incubation of the protease sample and substrate, the reaction was acidified with the addition of trichloroacetic acid (TCA). The mixture was then centrifuged with the undigested substrate, forming a pellet and the smaller acid-soluble fragments remaining in solution. The supernatant was neutralized, and the fluorescence of the FITC-labeled fragments was measured.

\section{Statistical analysis:}

The experiment was consisted of four treatments arranged in a $2 \times 2$ factorial design (2 protein and 2 lipid levels) with three replicates. Data were subjected to two-way analysis of variance (ANOVA), followed by a comparison of means (Tukey's HSD test) to test the effects of the dietary protein and lipid levels on fish performance. $P<0.05$ was regarded as statistically significant. If significant $(\mathrm{p}<0.05)$ differences were found in factors, Duncan's multiple range test (Duncan, 1955) was used to rank the means. All statistics were processed using the SPSS package (version 23.0). 


\section{RESULTS}

\section{Growth performance:}

Dietary protein and lipid levels either individually or in a combination had significant effects on final weight (FW), weight gain ratio (WGR), daily gain index (DGI) and specific growth rate (SGR) of fish (Table 2). Fish fed on P40L12 and P40L6 diets gave the best FW, WGR, DGI and SGR, followed by P30L6 and P30L12. With respect to dietary protein and lipid levels as single factors, WG, FW, WGR, DGI and SGR were higher in fish fed diets with protein level $40 \%$ compared to fish fed diets with $30 \%$, and they were not significantly different in fish fed diets with $6 \%$ or $12 \%$ lipid levels.

\section{Nutrients utilization}

The effects of the experimental diets on feed utilization of $S$. rivulatus are shown in Table (3). The best feed conversion ratio (FCR), Feed efficiency (FE), protein retention (PR) and protein efficiency ratio (PER) were found in fish fed the P40L6 and P40L12 diets, while P30L6 and P30L12 gave the worst results of those parameters. With respect to dietary protein and lipid levels as single factors, the best results of FCR, FE, PR, PER and EG were obtained in fish fed the diets with $40 \%$ protein compared to fish fed the diets with $30 \%$ protein. However, FCR, FE, PER, PR and EG were not affected by dietary lipid levels.

Table (2): Effects of dietary protein and lipid levels on growth performance and survival of $S$. rivulatus

\begin{tabular}{|c|c|c|c|c|c|c|c|}
\hline \multicolumn{2}{|c|}{ Diet } & \multicolumn{6}{|c|}{ Growth performances } \\
\hline Protein & Lipid & $\begin{array}{c}\text { Survival } \\
(\%)\end{array}$ & $\begin{array}{l}\text { IW } \\
(\mathrm{g})\end{array}$ & $\begin{array}{c}\text { FW } \\
(\mathrm{g})\end{array}$ & $\begin{array}{c}\text { WGR } \\
(\%)\end{array}$ & $\begin{array}{c}\text { DGI } \\
(\%)\end{array}$ & $\begin{array}{c}\text { SGR } \\
\left(\% \text { day }^{-1}\right)\end{array}$ \\
\hline \multicolumn{8}{|c|}{ Double factor } \\
\hline \multirow{2}{*}{ P30 } & L6 & $80.0 \pm 0.12^{b}$ & $0.33 \pm 0.02^{\mathrm{a}}$ & $1.55 \pm 0.07^{\mathrm{b}}$ & $375.7 \pm 0.16^{b}$ & $0.73 \pm 0.04^{\mathrm{b}}$ & $2.79 \pm 0.01^{\mathrm{b}}$ \\
\hline & L12 & $83.3 \pm 3.34^{\mathrm{b}}$ & $0.33 \pm 0.01^{\mathrm{a}}$ & $1.85 \pm 0.06^{\mathrm{b}}$ & $461.8 \pm 34.60^{\mathrm{b}}$ & $0.91 \pm 0.05^{\mathrm{b}}$ & $3.08 \pm 0.11^{\mathrm{b}}$ \\
\hline \multirow{2}{*}{$\mathbf{P 4 0}$} & L6 & $96.7 \pm 3.33^{\mathrm{a}}$ & $0.32 \pm 0.01^{\mathrm{a}}$ & $2.57 \pm 0.01^{\mathrm{a}}$ & $713.5 \pm 14.42^{\mathrm{a}}$ & $1.34 \pm 0.01^{\mathrm{a}}$ & $3.74 \pm 0.03^{\mathrm{a}}$ \\
\hline & L12 & $96.7 \pm 2.34^{\mathrm{a}}$ & $0.30 \pm 0.00^{\mathrm{a}}$ & $2.31 \pm 0.01^{\mathrm{a}}$ & $666.5 \pm 6.97^{\mathrm{a}}$ & $1.20 \pm 0.01^{\mathrm{a}}$ & $3.64 \pm 0.01^{\mathrm{a}}$ \\
\hline \multicolumn{8}{|c|}{ Single factor } \\
\hline \multirow{2}{*}{\multicolumn{2}{|c|}{$\begin{array}{l}\text { P30 } \\
\text { P40 }\end{array}$}} & $81.7 \pm 1.67^{b}$ & $0.33 \pm 0.01^{\mathrm{a}}$ & $1.70 \pm 0.09^{b}$ & $418.7 \pm 28.59^{b}$ & $0.82 \pm 0.06^{b}$ & $2.93 \pm 0.10^{\mathrm{a}}$ \\
\hline & & $96.7 \pm 1.93^{\mathrm{a}}$ & $0.31 \pm 0.01^{\mathrm{a}}$ & $2.45 \pm 0.08^{\mathrm{a}}$ & $690.1 \pm 15.05^{\mathrm{a}}$ & $1.27 \pm 0.04^{\mathrm{a}}$ & $3.69 \pm 0.03^{\mathrm{a}}$ \\
\hline & L6 & $88.3 \pm 5.00^{\mathrm{a}}$ & $0.32 \pm 0.01^{\mathrm{a}}$ & $2.06 \pm 0.29^{\mathrm{a}}$ & $544.6 \pm 97.72^{\mathrm{a}}$ & $1.03 \pm 0.18^{\mathrm{a}}$ & $3.26 \pm 0.28^{\mathrm{a}}$ \\
\hline & L12 & $90.0 \pm 4.30^{\mathrm{a}}$ & $0.32 \pm 0.01^{\mathrm{a}}$ & $2.08 \pm 0.13^{\mathrm{a}}$ & $564.2 \pm 60.86^{\mathrm{a}}$ & $1.05 \pm 0.09^{\mathrm{a}}$ & $3.36 \pm 0.17^{\mathrm{a}}$ \\
\hline
\end{tabular}

Note: Means in the same column bearing different superscripts differ significantly at 0.05 levels. Values are means $\pm S D$. 
Table (3): Effects of dietary protein and lipid levels on nutrient utilization of S. rivulatus

\begin{tabular}{|c|c|c|c|c|c|c|}
\hline \multicolumn{2}{|c|}{ Diet } & \multicolumn{5}{|c|}{ Nutrient utilization } \\
\hline Protein & Lipid & FCR & FE $(\%)$ & $\operatorname{PER}(\mathrm{g})$ & PR (\%) & EG (Kcal) \\
\hline \multicolumn{7}{|c|}{ Double factor } \\
\hline \multirow{2}{*}{ P30 } & L6 & $2.16 \pm 0.04^{\mathrm{a}}$ & $46.34 \pm 0.89^{b}$ & $1.54 \pm 0.03^{b}$ & $51.72 \pm 1.36^{\mathrm{c}}$ & $1.52 \pm 0.07^{b}$ \\
\hline & L12 & $1.98 \pm 0.05^{\mathrm{b}}$ & $50.45 \pm 1.27^{\mathrm{b}}$ & $1.65 \pm 0.04^{\mathrm{a}}$ & $60.86 \pm 3.64^{b}$ & $1.56 \pm 0.11^{\mathrm{b}}$ \\
\hline \multirow{2}{*}{ P40 } & L6 & $1.73 \pm 0.02^{\mathrm{c}}$ & $57.84 \pm 0.47^{\mathrm{a}}$ & $1.41 \pm 0.01^{\mathrm{c}}$ & $79.33 \pm 2.65^{\mathrm{a}}$ & $3.19 \pm 0.11^{\mathrm{a}}$ \\
\hline & L12 & $1.78 \pm 0.03^{\mathrm{c}}$ & $56.26 \pm 0.63^{\mathrm{a}}$ & $1.39 \pm 0.02^{c}$ & $74.58 \pm 3.32^{\mathrm{a}}$ & $2.99 \pm 0.16^{\mathrm{a}}$ \\
\hline \multicolumn{7}{|c|}{ Single factor } \\
\hline P30 & & $2.07 \pm 0.06^{\mathrm{a}}$ & $48.39 \pm 1.34^{b}$ & $1.60 \pm 0.04^{\mathrm{a}}$ & $56.29 \pm 3.08^{b}$ & $1.54 \pm 0.05^{b}$ \\
\hline P40 & & $1.75 \pm 0.02^{\mathrm{b}}$ & $57.05 \pm 0.56^{\mathrm{a}}$ & $1.40 \pm 0.01^{\mathrm{b}}$ & $76.96 \pm 2.21^{\mathrm{a}}$ & $3.09 \pm 0.09^{\mathrm{a}}$ \\
\hline & L6 & $1.94 \pm 0.13^{\mathrm{a}}$ & $52.09 \pm 3.34^{\mathrm{a}}$ & $1.48 \pm 0.04^{\mathrm{a}}$ & $65.52 \pm 8.07^{\mathrm{a}}$ & $2.35 \pm 0.49^{\mathrm{a}}$ \\
\hline & L12 & $1.88 \pm 0.06^{\mathrm{a}}$ & $53.36 \pm 1.78^{\mathrm{a}}$ & $1.52 \pm 0.08^{\mathrm{a}}$ & $67.72 \pm 4.44^{\mathrm{a}}$ & $2.28 \pm 0.42^{\mathrm{a}}$ \\
\hline
\end{tabular}

Note: Means in the same column bearing different superscripts differ significantly at 0.05 levels. Values are means $\pm S D$.

\section{Carcass chemical composition}

There was a significant interaction between the dietary protein and lipid levels on crude protein, lipid contents and gross energy (Table 4). Results showed that crude protein, crude lipid contents and gross energy of fish were influenced by dietary protein levels but not by lipid levels $(P>0.05)$. The highest values of $\mathrm{CP}, \mathrm{CL}$ and GE were recorded at P40 regardless the lipid level. On the other hand, there was no significant interaction between the dietary protein and lipid levels on moisture and ash contents.

\section{Fish digestive enzymes}

The dietary levels of protein and lipids have been well reflected on the digestive enzymes of fish (Table 5). The highest value of protease has been recorded at protein level P40 regardless the lipid level followed by P30L12 treatment, while the lowest value has been obtained at P30L6. Fish fed on P30L6, P30L12, P40L6 to P40L12 showed an increase in lipase upward, respectively. The highest result of amylase has been detected in P30L6 followed by P30L12 and P40L6 at the same level, while the lowest value has been given at P40L12. The highest value of glutamate dehydrogenase has been given at P30L6 followed by P30L12 and then P40, regardless the lipid level. 
TABLE (4): Effects of dietary protein and lipid levels on whole-body composition of $S$. rivulatus (\% wet weight)

\begin{tabular}{|c|c|c|c|c|c|c|}
\hline \multirow{2}{*}{\multicolumn{2}{|c|}{ Diet }} & \multicolumn{5}{|c|}{ Body composition (\%) } \\
\hline & & \multirow{2}{*}{ Moisture } & \multirow{2}{*}{$\begin{array}{l}\text { Crude } \\
\text { protein }\end{array}$} & \multirow{2}{*}{$\begin{array}{c}\text { Ether } \\
\text { extract }\end{array}$} & \multirow{2}{*}{$\begin{array}{c}\text { Gross energy } \\
(\mathbf{K J} / \mathbf{g})\end{array}$} & \multirow{2}{*}{ Ash } \\
\hline Protein & Lipid & & & & & \\
\hline \multicolumn{7}{|c|}{ Double factor } \\
\hline \multirow[t]{2}{*}{ P30 } & L6 & $79.34 \pm 0.07^{\mathrm{a}}$ & $12.59 \pm 0.09^{b}$ & $4.06 \pm 0.15^{\mathrm{c}}$ & $4.57 \pm 0.08^{b}$ & $4.13 \pm 0.01^{\mathrm{a}}$ \\
\hline & L12 & $75.85 \pm 1.54^{\mathrm{a}}$ & $13.09 \pm 0.77^{\mathrm{b}}$ & $5.74 \pm 0.46^{\mathrm{b}}$ & $5.35 \pm 0.36^{\mathrm{ab}}$ & $5.17 \pm 0.26^{\mathrm{a}}$ \\
\hline \multirow[t]{2}{*}{ P40 } & L6 & $74.63 \pm 0.37^{\mathrm{a}}$ & $14.46 \pm 0.35^{\mathrm{a}}$ & $6.39 \pm 0.18^{\mathrm{a}}$ & $5.93 \pm 0.15^{\mathrm{a}}$ & $4.09 \pm 0.07^{\mathrm{a}}$ \\
\hline & L12 & $74.72 \pm 0.34^{\mathrm{a}}$ & $15.00 \pm 0.53^{\mathrm{a}}$ & $6.73 \pm 0.16^{\mathrm{a}}$ & $6.19 \pm 0.19^{\mathrm{a}}$ & $3.55 \pm 0.12^{\mathrm{a}}$ \\
\hline \multicolumn{7}{|c|}{ Single factor } \\
\hline \multicolumn{2}{|c|}{ P30 } & $77.59 \pm 1.19^{a}$ & $12.84 \pm 0.35^{b}$ & $4.90 \pm 0.52^{b}$ & $4.96 \pm 0.27^{b}$ & $4.65 \pm 0.32^{a}$ \\
\hline \multicolumn{2}{|l|}{ P40 } & $74.68 \pm 0.21^{\mathrm{a}}$ & $14.73 \pm 0.30^{\mathrm{a}}$ & $6.56 \pm 0.14^{\mathrm{a}}$ & $6.06 \pm 0.12^{\mathrm{a}}$ & $3.82 \pm 0.16^{\mathrm{a}}$ \\
\hline & L6 & $77.03 \pm 1.34^{\mathrm{a}}$ & $13.79 \pm 0.73^{\mathrm{a}}$ & $5.39 \pm 0.78^{b}$ & $5.38 \pm 0.48^{\mathrm{a}}$ & $3.84 \pm 0.17^{\mathrm{a}}$ \\
\hline & L12 & $75.24 \pm 0.74^{\mathrm{a}}$ & $13.77 \pm 0.52^{\mathrm{a}}$ & $6.06 \pm 0.27^{\mathrm{a}}$ & $5.64 \pm 0.23^{\mathrm{a}}$ & $4.63 \pm 0.33^{a}$ \\
\hline
\end{tabular}

Note: Means in the same column bearing different superscripts differ significantly at 0.05 levels. Values are means $\pm S D$.

Table (5): Effects of dietary protein and lipid levels on digestive enzymes of S. rivulatus

\begin{tabular}{|c|c|c|c|c|c|}
\hline \multicolumn{2}{|c|}{ Diet } & \multicolumn{4}{|c|}{ Digestive enzymes } \\
\hline Protein & Lipid & $\begin{array}{c}\text { Protease } \\
\left.\text { (U mg } \text { }^{-1} \text { prot }\right)\end{array}$ & $\begin{array}{c}\text { Lipase } \\
\text { (U mg } \text { }^{-1} \text { prot) }\end{array}$ & $\begin{array}{c}\text { Amylase } \\
\text { (U mg } \text { }^{-1} \text { prot) }\end{array}$ & $\begin{array}{c}\text { Glutamate } \\
\text { dehydrogenase } \\
\text { (U mg-1 prot) }\end{array}$ \\
\hline \multicolumn{6}{|c|}{ Double factor } \\
\hline \multirow{2}{*}{ P30 } & $\mathrm{L6}$ & $28.00 \pm 3.00^{c}$ & $9.21 \pm 0.67^{d}$ & $0.62 \pm 0.03^{\mathrm{a}}$ & $11.98 \pm 0.07^{\mathrm{a}}$ \\
\hline & L12 & $45.00 \pm 3.00^{\mathrm{b}}$ & $13.31 \pm 1.05^{\mathrm{c}}$ & $0.46 \pm 0.02^{b}$ & $10.50 \pm 0.10^{\mathrm{b}}$ \\
\hline \multirow{2}{*}{ P40 } & L6 & $90.00 \pm 2.00^{\mathrm{a}}$ & $12.22 \pm 0.64^{\mathrm{b}}$ & $0.45 \pm 0.01^{\mathrm{b}}$ & $9.16 \pm 0.10^{c}$ \\
\hline & L12 & $92.50 \pm 2.50^{\mathrm{a}}$ & $16.93 \pm 0.19^{\mathrm{a}}$ & $0.34 \pm 0.05^{\mathrm{c}}$ & $8.90 \pm 0.08^{c}$ \\
\hline \multicolumn{6}{|c|}{ Single factor } \\
\hline P30 & & $36.50 \pm 5.20^{b}$ & $11.26 \pm 1.03^{b}$ & $0.54 \pm 0.02^{\mathrm{a}}$ & $11.24 \pm 0.83^{\mathrm{a}}$ \\
\hline $\mathbf{P 4 0}$ & & $91.25 \pm 1.49^{\mathrm{a}}$ & $14.57 \pm 0.83^{\mathrm{a}}$ & $0.40 \pm 0.04^{\mathrm{b}}$ & $9.03 \pm 0.28^{\mathrm{b}}$ \\
\hline & L6 & $59.00 \pm 7.96^{b}$ & $10.71 \pm 1.82^{b}$ & $0.53 \pm 0.02^{\mathrm{a}}$ & $10.57 \pm 0.61^{\mathrm{a}}$ \\
\hline & L12 & $68.75 \pm 3.80^{\mathrm{a}}$ & $15.12 \pm 1.23^{\mathrm{a}}$ & $0.39 \pm 0.03^{b}$ & $9.70 \pm 0.08^{\mathrm{a}}$ \\
\hline
\end{tabular}

Note: Means in the same column bearing different superscripts differ significantly at 0.05 levels. Values are means $\pm S D$. 


\section{DISCUSSION}

In the present study, the results showed that growth performance of fish significantly increased with an increase of the dietary protein level, regardless of the lipid level. The protein requirement for the best growth performance of the rabbitfish has been found at $40 \%$. This protein requirement is in line with the previously reported protein level for Siganus rivulatus (El-Dakar et al., 2011 and Abou-Daoud et al., 2014). However, the dietary protein requirement determined in this study for S. rivulatus is higher than those values reported for another rabbitfish species $S$. guttutus fry, which were $25-35 \%$, (Soletchnik, 1984 and Parazo, 1990). It is evident therefore that difference in protein requirements among Siganus species is logical and acceptable, which emphasizes a fact that says 'a protein requirement is species specific'. From another perspective, this high dietary protein requirement in the current study, comparing to other omnivore species, might be attributable to their feeding habits in that early life stage. It has been indicated that as fish increases in size and age, their protein requirement tends to decrease (Halver \& Hardy, 2002). In the current study, fish fed on diets containing $30 \%$ protein gave lower growth performance and feed utilization efficiency values. This indicated that the dietary protein did not meet Siganus requirements at this early stage, which might be due to the insufficient amount of essential amino acids available to the fish (Coutinho et al., 2016). Indeed, fish at early stage have high requirements for protein to be broken down into amino acids, which are then used mainly for the rapid growth and as an energy source (Conceicao et al., 1997). In support, it was found that the optimal protein:energy ratio for the Siganus canaliculatus fingerlings was lower than that of the fry group. This may confirm that higher protein requirements for early development of fry decrease with increasing fish size (Yousif et al., 1996).

FCR and PER are known to decrease with an increase of dietary protein content (Jauncey, 1982). In the present study, FCR was significantly decreased by increasing dietary protein levels, regardless the dietary lipid level. However, at protein level $30 \%$, it showed a tendency to decrease by increasing the lipid level from 6 to $12 \%$, indicating that the low level of dietary lipid (6\%) could meet the best feed conversion ratio needs of Siganus rivulatus at a protein level $40 \%$. This is supported by El-Dakar et al. (2011). In the present study, the PER decreased with the increase in the dietary protein level, which is consistent with other reports (Shapawi et al., 2013). The decreased FCR and PER indicated that diets contained higher protein level in the present study were better utilized in Siganus.

Dietary protein impacts fish survival (Arredondo-Figueroa et al., 2012). In fact, after the eight-weeks experiment, fish fed on diets containing higher protein contents (P40L6 and P40L12) also showed a higher survival rate. This was parallel to the growth rate results, indicating that a $40 \%$ protein level was sufficient for the performance of $S$. rivulatus. This is in agreement with Aliyu-Paiko et al. (2010) who indicated that a lipid: 
protein ratio of 6:45 gave the best survival rate in Snakehead (Channa striatus), but other diets with lower protein content produced a lower survival rate.

Furthermore, in the present study, the level of dietary lipid did not exhibit a significant effect on the growth performance or feed utilization of fish. This indicates that the low level of dietary lipid (6\%) could meet the growth needs of Siganus rivulatus with protein level $40 \%$. The lipid requirement recorded in the current study may be lower than that recorded for $S$. rivulatus in another study, which was $9.8 \%$ (Ghanawi et al., 2011). This may be attributed to the lower dietary protein level (30\%) used in Ghanawi $\boldsymbol{e t}$ al. (2011) which requires more lipid content to maintain the energy required for fish.

On the other side, this result is consistent with recorded lipid levels for other omnivorous fish species, such as 5.5-8.5\% for hybrid tilapia (Oreochromis niloticus $x O$. aureus) (Han et al., 2011), $6 \%$ For Nile tilapia (Oreochromis niloticus) (Abdel-Ghany, 2017), and 5\% for Ussuri catfish (Pseudobagrus ussuriensis) fingerlings (Wang et al., 2011). Many studies have pointed out that increasing dietary lipid or energy levels has a protein-saving effect on fish (Luo et al., 2005 and Chatzifotis et al., 2010). However, this effect is not observed in the present study. Similarly, the protein-sparing effect of dietary lipid was not observed in previous studies (Wang et al., 2005 and Wang et al., 2017). This discrepancy in results may be due to the differences in fish life stages, fish species, feed composition and feeding strategies (Yan et al., 2015).

Although the body composition of $S$. rivulatus was found to be dependent upon the dietary treatments in the current study; however, whole-body moisture was not correlated to the dietary protein level. This is in parallel with the result obtained by Kim \& Lee (2009). In the current study, the protein content increased with the increase of dietary protein-to-energy ratio. Previous study reported similar trend (Yousif et al., 1996). In the present study, the muscle lipid content in marbled spinefoot increased with increasing the dietary lipid levels, reflecting the tendency for some lipid deposition in the muscle. These results are similar to those reported by other authors (Lee et al., 2002; Wang et al., 2005 and Sandre et al., 2017). These results suggest that the marbled spinefoot used the surplus lipid to enhance the fat deposition rather than metabolizing energy to spare the protein. Although some authors indicated that the major site for fat and glycogen deposition in some fishes is the liver (Hemre et al., 2002). In the present study, liver did not contribute significantly to the lipid deposition in the marbled spinefoot, which is similar to results obtained by Ghanawi et al. (2011).

Digestive enzymes such as protease, amylase and lipase correlate positively with any increase in dietary protein, lipid and carbohydrates (Buddington \& Krogdahl, 2004; Zambonino et al., 2007 and García-Meilán et al. 2013). Following the same pattern, a difference in the protease activity among the different treatments was detected in the current study. The total protease activity progressively increased as the diet protein content increased from 30 to $40 \%$. This is in agreement with García-Meilán et al. (2013) 
who found a progressive increase in the total protease activity in the sea bream (Sparus aurata) alimentary canal as the content of diet protein increased from 35 to $41 \%$. As well, the lipase activity responded to the dietary lipid levels in the present study. Apparently, diets containing less crude lipid level, induced the lowest lipase activity throughout the alimentary tract (Mohanta et al., 2008 and Dizhi et al., 2018). In this study, the carbohydrate contents were varied among the different diets. This variation in carbohydrate content may be attributed to the different levels of starch included in each diet. Overall, a positive correlation between amylase activity and diets carbohydrate content was reported in the current study, which is supported by Li et al. (2016).

Glutamate dehydrogenase $(\mathrm{GDH})$ is considered as a significant marker/regulator for nutrients utilization, especially protein utilization (Rønnestad et al., 1999). Therefore, GDH could be a useful indicator of the metabolic utilization of dietary components by fish (Rønnestad $\boldsymbol{e t}$ al., 1999). Furthermore, the increased GDH activity is probably associated with a high-protein feeding (Sanchez-Muros et al., 1998). On the contrary, in the present study, the high level of protein level was accompanied with the lowest level of GDH and vice versa. These results were confirmed by Cowey \& Walton (1989) who revealed that usually after long-term feeding with a low protein diet, the GDH expressions increased to induce protein metabolism and meet the compensatory growth.

The overall results in this study indicated that dietary protein and lipid levels at $40 \%$ and at $6 \%$, respectively, gave the best growth rate and feed utilization efficiency. Increasing the level of lipid in the rabbitfish (S. rivulatus) juveniles diet to $12 \%$ does not differ significantly from the lower level.

Conflict of Interest: The authors declare that they have no conflict of interest.

Ethical approval: All applicable international, national, and/or institutional guidelines for the care and use of animals were followed by the authors.

\section{REFERENCES}

Abdel-Ghany, H.M. (2017). Effects of dietary lipids on cold tolerance of Nile tilapia (Oreochromis niloticus). PhD dissertation. University of Alexandria, Alexandria, Egypt.

Abou-Daoud, Y.; Ghanawi, J.; Farran, M.; Davis, D. A. and Saoud, I.P. (2014). Effect of Dietary Protein Level on Growth Performance and Blood Parameters of Marbled Spinefoot Siganus rivulatus. Journal of Applied Aquaculture, 26: 103-118.

Aliyu-Paiko, M.; Hashim, R. and Shu-Chien, A.C. (2010). Influence of dietary lipid/protein ratio on survival, growth, body indices and digestive lipase activity in 
Snakehead (Channa striatus, Bloch 1793) fry reared in re-circulating water system. Aquaculture Nutrition, 16: 466-474.

Anastasiades, G. (2011). Biodiversity in eastern Mediterranean marine aquaculture: An approach to new species. $\mathrm{PhD}$ dissertation, University of Insubria, Varese, Italy.

AOAC (2009). Official methods of analysis of AOAC International (17th ed.). Arlington, VA: Assoc. Official Analytical Chemists.

Arredondo-Figueroa, J.L.; Matsumoto-Soulé, J.J. and Ponce-Palafox, J.T. (2012). Effects of protein and lipids on growth performance, feed Efficiency and survival rate in fingerlings of bay snook (Petenia splendida). International Journal of Animal and Veterinary Advances, 4: 204-213.

Beamish, F.W.H. and Medland, T.E. (1986). Protein sparing effects in large rainbow trout, Salmo gairdneri. Aquaculture, 55: 35-42.

Buddington, R.K.; Krogdahl, A. and Bakke-Mckellep, A.M. (1997). The intestine of carnivorous fish: structure and functions and the relations with diet. Acta Physiologica Scandinavica, 161: 67-80.

Buddington, R.K. and Krogdahl, А. (2004). Hormonal regulation of the fish gastrointestinal tract. Comp Biochem Phys A Mol Integr Physiol., 139(3): 261-271.

Catacutan, M.R. and Coloso, R.M. (1995). Effect of dietary protein to energy ratios on growth, survival, and body composition of juvenile Asian (seabass, Lates calcarifer ). Aquaculture, 131: 125-133.

Chaitanawisuti, N.; Kritsanapuntu, S. and Santaweesuk, W. (2011). Effects of dietary protein and lipid levels and protein to energy ratios on growth performance and feed utilization of hatchery-reared juvenile spotted babylon (Babylonia areolata). Aquaculture International, 19: 13-21.

Chatzifotis, S.; Panagiotidou, M.; Papaioannou, N.; Pavlidis, M.; Nengas, I. and Mylonas, C.C. (2010). Effect of dietary lipid levels on growth, feed utilization, body composition and serum metabolites of meager (Argyrosomus regius) juveniles. Aquaculture, 307: 65-70.

Conceição, L.E.C.; Houlihan, D.F. and Verreth, J.A.J. (1997). Fast growth, protein turnover and costs of protein metabolism in yolk-sac larvae of the African catfish (Clarias gariepinus). Fish Physiology and Biochemistry, 16: 291-302.

Coutinho, F.; Peres, H.; Castro, C.; Pérez Jiménez, A.; Magalhães, R.; Pousão Ferreira, P. and Oliva Teles, A. (2016). Dietary protein requirement of zebra sea bream (Diplodus cervinus, Lowe 1838) juveniles. Aquaculture Nutrition, 22: 465471.

Cowey, C. and Walton, M. (1989). Intermediary metabolism. In: Halver, J.E., (ed) Fish nutrition. Academic Press, New York.

Dizhi, X.; Shude, X.; Qingyang, W.; Fang, C.; Shuqi, W.; Cuihong, Y. and Yuanyou, L. (2018). Changes of visceral properties and digestive enzymes in the herbivorous marine teleost Siganus canaliculatus fed on different diets. Acta Oceanologica Sinica, 37: 85-93. 
El-Dakar, A.Y.; Shalaby, S.M. and Saoud, P. (2011). Dietary protein requirement of juvenile marbled spinefoot rabbitfish Siganus rivulatus. Aquaculture Research, 42: 1050-1055.

García-Meilán, I.; Valentín, J.M.; Fontanillas, R. and Gallardo, M.A. (2013). Different protein to energy ratio diets for gilthead sea bream (Sparus aurata): Effects on digestive and absorptive processes. Aquaculture, 412-413: 1-7.

German, D.P.; Nagle, B.C.; Villeda, J.M.; Ruiz, A.M.; Thomson, A.W. and Balderas, S.C. (2010). Evans D.H. Evolution of herbivory in a carnivorous clade of minnows (Teleostei: cyprinidae): effects on gut size and digestive physiology. Physiological and Biochemical Zoology, 83: 1-18.

Ghanawi, J.; Roy, L.; Davis, D.A. and Saoud, I.P. (2011). Effects of dietary lipid levels on growth performance of marbled spinefoot rabbitfish, Siganus rivulatus. Aquaculture, 310: 395-400.

Halver, J. E. and Hardy, R.W. (2002). Fish nutrition, $3^{\text {rd }}$ ed., San Diego: Academic Press, p: 144-170.

Han, J.; Kamber, M. and Pei, J. (2011). Data mining: concepts and techniques. Elsevier Science. Retrieved from https://www.elsevier.com/books/data-mining-concepts-andtechniques/han/978-0-12-381479-1.

Hardy, R.W. (1999). Problems and opportunities in fish feed formulation. Aquaculture Magazine, 25: 56-60.

Hemre, G.I.; Mommsen, T.P. and Krogdahl, Å. (2002). Carbohydrates in fish nutrition: effects on growth, glucose metabolism and hepatic enzymes. Aquaculture Nutrition, 8: $175-194$.

Jauncey, K. (1982). The effect of varying dietary protein level on growth, food conversion, protein utilization and body composition of juvenile tilapias (Surotherodon mossambicus). Aquaculture, 27: 43-54.

Kaushik, S.J. and Seiliez, I. (2010). Protein and amino acid nutrition and metabolism in fish: Current knowledge and future needs. Aquaculture Research, 41: 322-332.

Kim, S.S. and Lee, K.J. (2009). Dietary protein requirement of juvenile tiger pu!er (Takifugu rubripes). Aquaculture, 287: 219-222.

Lam, T.J. (1974). Siganids: Their biology and mariculture potential. Aquaculture, 3: 325354.

Lee, S.-M.; Jeon, I.G. and Lee, J.Y. (2002). Effects of digestible protein and lipid levels in practical diets on growth, protein utilization and body composition of juvenile rockfish (Sebastes schlegeli). Aquaculture, 211: 227-239.

Lin, Y.H. and Shiau, S.Y. (2003). Dietary lipid requirement of grouper, Epinephelus malabaricus, and effects on immune responses. Aquaculture, 225: 243-250.

Li, X.; Zhu, X.; Han, D.; Yang, Y.; Jin, J. and Xie, S. (2016). Carbohydrate utilization by herbivorous and omnivorous freshwater fish species: a comparative study on gibel carp (Carassius auratus gibelio. Var CAS III) and grass carp (Ctenopharyngodon idellus). Aquaculture Research, 47: 128-139. 
López, L.M.; Durazo, E.; Viana, M.T.; Drawbridge, M. and Bureau, D.P. (2009). Effect of dietary lipid levels on performance, body composition and fatty acid profile of juvenile white seabass, Atractoscionnobilis. Aquaculture, 289: 101-105.

Lovell, R.T. (1998). Nutrition and feeding of fish, 2nd ed. London: Kluwer Academic Publishers.

Luo, Z.; Liu, Y.J.; Mai, K.S.; Tian, L.X.; Liu, D.H.; Tan, X.Y. and Lin, H.Z. (2005). Effect of dietary lipid level on growth performance, feed utilization and body composition of grouper Epinephelus coioides juveniles fed isonitrogenous diets in floating netcages. Aquaculture International, 13: 257-269.

Martino, R.C.; Cyrino, J.E.P.; Portz, L. and Trugo, L.C. (2002). Effect of dietary lipid level on nutritional performance of the surubim, Pseudoplatystomacorruscans. Aquaculture, 209: 209-218.

Mohanta, K.N.; Mohanty, S.N.; Jena, J.K. and Sahu, N.P. (2008). Protein requirement of silver barb, Puntius gonionotus Fingerlings. Aquaculture Nutrition, 14: 143-152.

NRC. (1993). Nutrient Requirements of Fish. National Academy Press, Washington, DC., USA., ISBN-13: 9780309048910, Pages: 114.

Parazo, M.M. (1990). Effect of Dietary Protein and Energy Level on Growth, Protein Utilization and Carcass Composition of Rabbitfish, Sigunus guttatus. Aquaculture, 86: 41-49.

Rønnestad, I.; Thorsen, A. and Finn, R.N. (1999). Fish larval nutrition: a review of recent advances in the roles of amino acids. Aquaculture, 177: 201-216.

Sanchez-Muros, M.J.; Garcia-Rejon, L.; Garcia-Salguero, L.; De la Higuera, M. and Lupianez, J.A. (1998). Long-term nutritional effects on the primary liver and kidney metabolism in rainbow trout. Adaptive response to starvation and a high-protein, carbohydrate-free diet on glutamate dehydrogenase and alanine aminotransferase kinetics. The International Journal of Biochemistry \& Cell Biology, 30: 55-63.

Sandre, L.C.G.; Buzollo, H.; Nascimento, T.M.T.; Neira, L.M.; Jomori, R.K. and Carneiroa, D.J. (2017). Productive performance and digestibility in the initial growth phase of tambaqui (Colossoma macropomum) fed diets with different carbohydrate and lipid levels. Aquaculture Reports, 6: 28-34.

Santigosa, E.; García-Meilán, I.; Valentin, J.M.; Pérez-Sanchez, J.; Médale, F.; Kaushik, S. and Gallardo, M.A. (2011). Modifications of intestinal nutrient absorption in response to dietary fish meal replacement by plant protein sources in sea bream (Sparus aurata) and rainbow trout (Oncorhynchus mykiss). Aquaculture, 317: $146-154$.

Shapawi, R.; Ebi, I. and Yong, A. (2013). Soybean meal as a source of protein in formulated diets for tiger grouper, Epinephelus fuscoguttatus juvenile. Part I: effects on growth, survival, feed utilization and body compositions. Agricultural Sciences, 4: 317-323. 
Soletchnik, P. (1984). Aspects of nutrition and reproduction in Siganus guttatus with emphasis on applications in aquaculture. SEAFDEC Aquaculture Department, Iloilo, Philippines (Terminal Report).

Twining, S.S. (1984). Fluorescein Isothiocyanate-Labeled Casein Assay for Proteolytic Enzymes. Analytical Biochemistry, 143: 30-34.

Wang, C.; Hu, G.; Sun, P.; Gu, W.; Wang, B.; Xu, Q. and Liu, H. (2018). Effects of dietary protein at two lipid levels on growth, gonadal development, body composition and liver metabolic enzymes of brown trout (Salmo trutta fario) broodstock. Aquaculture Nutrition, 24: 1587-1598.

Wang, J.T.; Liu, Y.J.; Tian, L.X.; Mai, K.S.; Du, Z.Y.; Wang, Y. and Yang, H.J. (2005). Effect of dietary lipid level on growth performance, lipid deposition, hepatic lipogenesis in juvenile cobia (Rachycentron canadum). Aquaculture, 249: 439-447.

Wang, J.T.; Han, T.; Li, X.Y.; Yang, Y.X.; Yang, M.; Hu, S.X.; Jiang, Y.D. and Harpaz, S. (2017). Effects of dietary protein and lipid levels with different protein-toenergy ratios on growth performance, feed utilization and body composition of juvenile red-spotted grouper, Epinephelus akaara. Aquaculture Nutrition, 23: 994 1002.

Wang, Q.; Cheng, L.; Liu, J.; Li, Z.; Xie, S. and De Silva, S.S. (2011): Freshwater aquaculture in PR China: Trends and prospects. Rev. Aquacult., 7(4): 283-302.

Watanabe, T. (1982). Lipid nutrition in fish. Comparative Biochemistry and Physiology, 73: $3-15$.

Woodland, D.J. (1983). Zoogeography of the Siganidae (Pisces): an interpretation of distribution and richness patterns. Bulletin of Marine Science, 33: 713-717.

Yan, J.; Li, Y.; Liang, X.; Zhang, Y.; Dawood, M.A.O.; Matuli'c, D. and Gao, J. (2017). Effects of dietary protein and lipid levels on growth performance, fatty acid composition and antioxidant-related gene expressions in juvenile loach Misgurnus anguillicaudatus. Aquaculture Reasearch, 48: 5385-5393.

Yousif, O.M.; Osman, M.F.; Anawhi, A.A. and Cherian, T. (1996). Optimum proteinto-energy ratio for two size groups of rabbitfish, Siganus canaliculatus (Park). Aquaculture Nutrition, 2: 229-233.

Zambonino- Infante, J.L. and Cahu, C.L. (2007). Dietary modulation of some digestive enzymes and metabolic processes in developing marine fish: Applications to diet formulation. Aquaculture, 268: 98-105. 